\title{
Podpułkownik Marian Chodacki „Maracz” i jego dziedzictwo
}

\author{
Dominik Smyrgała, Dwa kroki przed przy- \\ szłością. Marian Chodacki jako wzór wspót- \\ czesnego analityka wywiadu, wyd. Wojskowy \\ Instytut Wydawniczy - Akademia Sztuki \\ Wojennej, Warszawa 2019, ss. 220
}

Trud odbudowy II Rzeczypospolitej po latach zaborów wymagał utworzenia od podstaw całego aparatu państwowego w postaci m.in. administracji, szkolnictwa, policji oraz sił zbrojnych. Zagrożenia stojące przed państwem polskim wymagały także zorganizowania odpowiednich struktur wywiadowczych. Publikacja autorstwa Dominika Smyrgały prezentuje sylwetkę ppłk. Mariana Chodackiego, oficera Wojska Polskiego, analityka wywiadu i dyplomaty. Co warte podkreślenia, Autor zaprezentował nie tylko drogę życiową oficera, której ważną częścią była służba dla Rzeczypospolitej, lecz także jego dorobek analityczny odnoszący się do kluczowych wówczas dla państwa polskiego zagadnień.

Omawiana książka zajmuje ważne miejsce wśród prac poświęconych dziejom polskiego wywiadu w latach 1918-1945. Publikacje te przybliżają jego organizację, metody i kierunki działania, jak również prezentują sylwetki służących w nim oficerów $\mathrm{WP}^{1}$. Badania te niejednokrotnie mają

\footnotetext{
${ }^{1}$ Najistotniejsze publikacje dotyczące wspomnianej tematyki powstałe w ostatnich kilku latach to: Wywiad wojskowy II Rzeczypospolitej. Materiały, red. P. Kołakowski, A. Pepłoński, Kraków 2011; P. Kołakowski, Czas próby. Polski wywiad wojskowy wobec groźby wybuchu wojny w 1939 roku, Warszawa 2012; A. Jendrzejewski, Polski wywiad wojskowy w Wolnym Mieście Gdańsku w latach 1920-1930, Gdańsk 2013; Ł. Ulatowski, Polski wywiad wojskowy w 1939 roku. Struktura organizacyjna, składy osobowe, personel, budżet, mob., Warszawa 2013; Za kulisami wywiadu i dyplomacji. Polski wywiad wojskowy 1918-1945. Materiały, red. P. Kołakowski, A. Pepłoński, Kraków 2014; P. Kołakowski, A. Krzak, Sprawa majora Jerzego Sosnowskiego $w$ świetle dokumentów analitycznych Oddziału II SGWP i zeznań Franza Heinricha Pfeifera, Warszawa 2015; Polski wywiad wojskowy 1918-1945, red. P. Kołakowski, A. Pepłoński, Toruń 2016; K. Paduszek, Zajrzeć do mózgu Lenina. Wywiad
} 
interdyscyplinarny charakter, gdyż wykorzystywane są w nich metody charakterystyczne dla kilku dziedzin naukowych, pośród których prócz historii wymienić należy nauki prawne, wiedzę z zakresu stosunków międzynarodowych i bezpieczeństwa wewnętrznego. Potwierdzeniem tego jest po części także książka Dominika Smyrgały, który swoją pracę sytuuje w dyscyplinie nauk o bezpieczeństwie ${ }^{2}$. Tym samym opracowanie wpisuje się w nowy, ale prężnie rozwijający się nurt badań.

U źródeł tej publikacji - do czego przyznaje się Autor - leży próba znalezienia odpowiedzi na pytanie, który z oficerów wywiadu II Rzeczypospolitej „mógłby służyć za swego rodzaju wzorzec wychowawczy oraz symbol wartości i cech pożądanych u młodego żołnierza i funkcjonariusza służb specjalnych III Rzeczypospolitej”3. Kryterium to według Autora spełnia bohater omawianej publikacji. Opinię tę o opisywanym oficerze podziela m.in. gen. bryg. Andrzej Kowalski, szef Służby Wywiadu Wojskowego w latach 2016-2020, który opatrzył książkę stosowną przedmową oraz objął jej wydanie patronatem. We wprowadzeniu podkreślił też, że staraniem SWW Chodacki pośmiertnie awansowany został na stopień podpułkownika WP4.

Co prawda życie i działalność Chodackiego - co skrzętnie odnotowuje Autor - przykuwały zainteresowanie wielu badaczy, lecz w większości przypadków ich prace nie miały kompleksowego charakteru ${ }^{5}$. Recenzowana publikacja wyróżnia się w tym zbiorze, gdyż prócz zaprezentowania biografii przybliża także spuściznę pisarską Chodackiego i jego zabiegi zmierzające do skutecznego ukrycia archiwum Samodzielnej Placówki Wywiadowczej „Estezet” w Nowym Jorku. Książka opisuje ponadto późniejszą działalność byłego dyplomaty w ramach Instytutu Józefa Piłsudskiego w Nowym Jorku.

Publikacja, jak konstatuje Autor, nie ma charakteru klasycznej biografii. Według jego zamysłu „życiorys jest w niej tylko przyczynkiem do zbadania

II Rzeczypospolitej a postrewolucyjna Rosja, Łomianki 2016; T. Dubicki, Ppłk Bolesław Ziemiański (1901-1976). Szef Ochrony Marszałka Józefa Piłsudskiego, oficer wywiadu polskiego w Rumunii w czasie II wojny światowej, Łomianki 2016. Wykaz ten trzeba uzupełnić poprzez wskazanie wydawnictw cyklicznych. Do tego zbioru należą: Sekretna wojna. $Z$ dziejów kontrwywiadu II RP, t. 1-3, red. Z. Nawrocki, Poznań 2014-2015; T. Dubicki, A. Suchcitz, Oficerowie wywiadu WP i PSZ w latach 1939-1945, t. 1, Warszawa 2009; t. 2, Warszawa 2011; t. 3, Warszawa 2018; Wywiad i kontrwywiad wojskowy. Studia i materiały $z$ działalności Oddziału II SGWP, t. 1-10, red. T. Dubicki, Łomianki 2010-2020.

${ }^{2}$ D. Smyrgała, Dwa kroki przed przyszłością. Marian Chodacki jako wzór współczesnego analityka wywiadu, Warszawa 2019.

${ }^{3}$ Ibidem, s. 11.

${ }^{4}$ Ibidem, s. 9.

${ }^{5}$ T. Aleksander, Marian Chodacki - ostatni Komisarz Generalny RP w Wolnym Mieście Gdańsku, „Rocznik Sądecki” 2013, t. XLI; P. Semków, Marian Stanisław Chodacki 1898-1975 (żołnierz, dyplomata, emigrant), „Niepodległość” 2006, t. LVI. 
innego, nie mniej fascynującego odkrycia - dorobku analitycznego «Maracza»" ${ }^{\circ}$. W rozdziale I zatytułowanym Źródła i metodologia Dominik Smyrgała zaprezentował wykorzystaną w książce bazę źródłową, którą podzielił na dwa zbiory. Pierwszy stanowią kolekcje archiwalne wykorzystane w trakcie prac nad czterema pierwszymi rozdziałami książki poświęconymi ujętym w ciągu chronologicznym kolejom życia Chodackiego. Konstruując tę część opracowania, Autor korzystał z dokumentów przechowywanych w Archiwum MSZ, Archiwum Państwowym w Gdańsku, Biurze Udostępniania i Archiwizacji Dokumentów Instytutu Pamięci Narodowej w Warszawie, Centralnym Archiwum Wojskowym Wojskowego Biura Historycznego, Instytucie Polskim i Muzeum im. gen. Sikorskiego w Londynie oraz Instytucie Józefa Piłsudskiego w Ameryce. Drugi zbiór źródeł tworzą wykorzystane w rozdziałach od piątego do ósmego pisma i analizy autorstwa Chodackiego. W nich Autor zaprezentował jego poglądy zrekonstruowane na podstawie pozostawionej spuścizny intelektualnej i zbiorów osobistych? ${ }^{7}$.

Dominik Smyrgała ocenił twórczość Chodackiego niezwykle wysoko, przyrównując ją - „Z zachowaniem wszelkich proporcji” - do klasycznego dzieła Niccola Machiavellego zatytułowanego Książę. Uzasadniając swoje stanowisko, Autor argumentuje, że „gdyby zebrać wszystkie pisma w jeden zwarty tekst, byłby to także traktat z zakresu filozofii politycznej i poradnik strategiczny, jednak dotyczący zagadnień współczesnych"8. Czyniąc to nawiązanie, zapowiada tym samym opublikowanie pism Chodackiego jako edycji źródłowej.

Wracając jednak do przytoczonego porównania polskiego oficera do florenckiego filozofa polityki, można je uznać za nazbyt śmiałe, chociaż da się też wskazać pewne elementy, które przemawiają za jego trafnością. Cechą dystynktywną pozostaje niewątpliwie uniwersalizm mechanizmów opisanych przez Machiavellego. Analizy Chodackiego charakteryzują się raczej mniejszą doniosłością i dotyczą szczegółowych zagadnień polityki realizowanej w konkretnym czasie w odniesieniu do spraw polskich. Jeśli chcielibyśmy dopatrywać się związków pomiędzy dokonaniami obu tych postaci, to uznać można, iż tezy Machiavellego, uznawanego za ojca realizmu politycznego, stanowiły inspirację dla rozważań Chodackiego?.

${ }^{6}$ D. Smyrgała, Dwa kroki przed przyszłością..., s. 20.

${ }^{7}$ Ibidem, s. 28.

${ }^{8}$ Ibidem, s. 21.

${ }^{9} \mathrm{~W}$ ciągu ostatnich lat badania nad pojęciem realizmu politycznego zaowocowały wieloma publikacjami. Do najważniejszych opracowań omawiających ten sposób myślenia politycznego należą: Realizm polityczny. Przypadek polski. Wybór tekstów, red. J. Kloczkowski, Kraków 2008; Między sercem a rozumem. Romantyzm i realizm w polskiej myśli politycznej, red. A. Citkowska-Kimla et al, Kraków 2017. 
Autor, prezentując dorobek pisarski Chodackiego, podkreśla, że poza kilkoma artykułami opublikowanymi przed wojną większość jego spuścizny pozostawała nieodkryta. Jej znaczenie potwierdza fakt, iż przygotowując swoje analizy, oficer „częstokroć trafnie przewidywał bieg wydarzeń w przyszłości, niekiedy z wyprzedzeniem kilku miesięcy, czasem kilku lat, czasami całych dekad". W opracowaniach tych wskazywał, że oficjalnym umowom czy traktatom towarzyszą zwykle bardziej istotne tajne protokoły czy uzupełnienia. Wyznacznikiem oryginalności myśli „Maracza”, co eksponuje Autor, są także wypracowane przez niego pojęcia czy koncepcje wyprzedzające jego epokę.

Dociekania Smyrgały oscylowały wokół dwóch ważnych zagadnień. Pierwszym było pytanie, czy koleje życia Chodackiego miały wpływ na jego myśl analityczną; drugim zaś, czy obecnie jego pisma cechują się uniwersalnością i przydatnością do oceniania współczesnych procesów politycznych oraz wynikających z nich zagrożeń. Autor wykorzystał badania biograficzne oraz fundamentalną dla nauk społecznych metodę dokumentalną.

Ograniczeniem dla badań biograficznych - co odnotowuje Autor - widocznym także w przypadku rekonstrukcji służby Mariana Chodackiego w Oddziale II Sztabu Generalnego WP, jest „niemal całkowity brak jakichkolwiek dokumentów". Trochę lepiej sytuacja rysuje się w przypadku jego służby w Ministerstwie Spraw Zagranicznych, gdzie pełnił funkcję Komisarza Generalnego RP w Wolnym Mieście Gdańsku. Jak stwierdza Autor, najwięcej dokumentów świadczących o życiu i działalności „Maracza” pochodzi ze zbiorów, które sam zachował i zabezpieczył przed zniszczeniem. Poza archiwum „Estezet” spuściznę tę tworzy kolekcja jego dokumentów przekazana do Instytutu Józefa Piłsudskiego w Nowym Jorku.

Wykorzystując zachowane archiwalia, Autor odtworzył w znacznej mierze - na ile to było możliwe - drogę życiową Chodackiego. W rozdziale drugim zaprezentował jego środowisko rodzinne oraz okres służby wojskowej przypadający na lata 1914-1932. Co istotne, od 1924 r. Chodacki służył w Oddziale II Sztabu Generalnego WP. W 1926 r. został kierownikiem Referatu "Zachód”, a rok później objął funkcję attaché wojskowego w Finlandii. W okresie tym debiutował jako analityk ${ }^{10}$. W jednym ze swoich tekstów już wówczas zwracał uwagę na niemiecki ekspansjonizm, który niezmiennie ukierunkowany był na opanowanie basenu Morza Bałtyckiego. Wówczas to proroczo wskazał jako ewentualne cele niemieckiej agresji Kłajpedę oraz polski korytarz, rozgraniczający Prusy Wschodnie i Niemcy.

Autor publikacji, prezentując karierę zawodową Chodackiego, za najważniejszy okres jego życia uznał lata 1933-1939. Przedstawił go w rozdziale

\footnotetext{
${ }^{10}$ Napisane w 1932 r. teksty analityczne pt. Problem Wielkiej Finlandii i sprawa karelska oraz Państwa bałtyckie wobec odrodzenia się hasła „Drang nach Osten” opublikowane zostały w miesięczniku „Polityka Narodów” w 1933 r. D. Smyrgała, Dwa kroki przed przyszłością..., s. 47-48.
} 
trzecim zatytułowanym Służba $w$ dyplomacji. Po przejściu do MSZ Chodacki pełnił obowiązki radcy w Departamencie Politycznym. W 1935 r. został pierwszym radcą w Poselstwie Polskim w Pradze, a w grudniu 1936 r. - Komisarzem Generalnym Rzeczypospolitej w Gdańsku. Nominacja ta sprawiła, że znalazł się w centrum ówczesnej polityki europejskiej, w której coraz mocniej odczuwalne było napięcie polsko-niemieckie, podsycane kolejnymi posunięciami Niemców o konfrontacyjnym charakterze wobec Polaków zamieszkujących Wolne Miasto Gdańsk, jak również wobec Polski. W swojej książce Smyrgała opisuje ten proces i postawę Chodackiego, który „z godnością bronił interesów Rzeczypospolitej”.

W rozdziale czwartym noszącym tytuł Drugi okres służby wojskowej i emigracja (1939-1975) Autor ukazał służbę Chodackiego w szeregach Wojska Polskiego na terenie Francji, Szkocji i Stanów Zjednoczonych Ameryki. W tej części książki zawarł także jego późniejsze emigracyjne losy aż do śmierci w 1975 r.

Dla właściwej oceny ówczesnej postawy Chodackiego istotne jest zwrócenie uwagi na jego niezależność w wyrażaniu opinii. Jej wyrazem, jak również potwierdzeniem osobistej odwagi było napisanie w maju 1941 r. memorandum do Winstona Churchilla, w którym argumentował, że wojna pomiędzy Niemcami a ZSRS jest „nieuchronna”. Co ważne, Chodacki należał też do krytyków paktu Sikorski-Majski. Opinię o tym porozumieniu wyartykułował w liście wysłanym do gen. Władysława Sikorskiego w sierpniu 1941 r. Dwa lata później w liście do Władysława Raczkiewicza, prezydenta RP na uchodźstwie, ze zdwojoną siłą przekonywał, że wchodzenie w układy z Sowietami jest złudne, podobnie jak oczekiwania co do respektowania przez nich przebiegu granicy wschodniej II RP.

Na początku 1944 r. Chodacki objął kierownictwo Samodzielnej Placówki Wywiadowczej „Estezet”, funkcjonującej na terenie Ameryki Południowej i Północnej. Kres działalności wywiadowczej „Estezetu” przyniosło cofnięcie 5 lipca 1945 r. przez dotychczasowych sprzymierzeńców (Wielką Brytanię i Stany Zjednoczone) uznania Rządowi RP na uchodźstwie ${ }^{11}$. Chodacki, obawiając się, że archiwalia kierowanej przez niego komórki mogą trafić w ręce komunistów, ukrył je w klasztorze Sióstr Nazaretanek w Torresdale w stanie Pensylwania. W 1959 r. potajemnie, zgodnie z jego wolą, trafiły one do Instytutu Piłsudskiego w Nowym Jorku.

\footnotetext{
${ }^{11}$ Wraz z rozwiązaniem Rady Jedności Narodowej 1 VII 1945 r. data ta wyznacza kres istnienia II Rzeczypospolitej. Umiejscowienie Polski w sowieckiej strefie wpływów oznaczało zarazem, że dotychczasowy Rząd RP na uchodźstwie „został pozbawiony wpływu na sprawy Polski i przestał być przeszkodą w dalszej budowie systemu władzy komunistów”; M. Korkuć, Fundamenty komunistycznej Polski (1945-1948) [w:] Komunizm w Polsce. Zdrada. Zbrodnia. Zakłamanie. Zniewolenie, Kraków, b.d.w., s. 200.
} 
Powtórzenie w recenzji - za Autorem - najistotniejszych elementów biografii ppłk. Chodackiego wydaje się uzasadnione, gdyż jego poglądy i analizy znajdowały potwierdzenie w dokonywanych wyborach życiowych i politycznych. Świadczy to niewątpliwie o autentyczności jego postawy.

Prócz przybliżenia czytelnikom biografii Chodackiego znaczną część (drugą) książki stanowi omówienie analiz jego autorstwa. Jak słusznie wskazuje Autor, wśród nich „problem Gdańska był jednym z najistotniejszych tematów publicystyki i działalności odczytowej"12. Dorobek ten - przez lata rozproszony i prawie zapomniany - powinien zostać wykorzystany, gdyż zawiera także, poza uwzględnieniem czynników wynikających z ekspansywnej polityki nazistów, dążących do zmian geopolitycznych w Europie, eksplikację błędów poczynionych przez ówczesne polskie władze. Świadczy to niewątpliwie o krytycyzmie i intelektualnej uczciwości Chodackiego.

Kolejną przestrzeń zainteresowań bohatera książki stanowiły kwestie interesów poszczególnych mocarstw w okresie II wojny światowej. Przedmiotem jego analiz pozostawała zwłaszcza polityka ZSRS i naiwny stosunek do niej państw zachodnich sprzymierzonych ze stalinowskim imperium w obliczu wojny z Niemcami. Chodacki słusznie przekonywał, że na Zachodzie zrozumienie istoty celów ZSRS jest uproszczone, gdyż w założeniu państwu temu poza pokonaniem nazizmu przyświecał jeszcze jeden cel rozszerzenie komunizmu na kolejne europejskie kraje. „Maracz” nie miał też złudzeń co do krańcowo pragmatycznego podejścia Wielkiej Brytanii do sprawy polskiej ${ }^{13}$. Aczkolwiek w dalszej perspektywie czasowej dostrzegał, że kolizja pomiędzy ZSRS a państwami demokracji zachodnich jest nieunikniona. W sposób najbardziej czytelny swoją epokę wyprzedził Chodacki, snując rozważania na temat wojny totalnej oraz wojny psychologicznej i walki informacyjnej. Z perspektywy współczesności jej przykłady widoczne są w aktualnej rywalizacji pomiędzy mocarstwami czy poszczególnymi państwami ${ }^{14}$.

${ }^{12}$ Zob. D. Smyrgała, Dwa kroki przed przyszłościq..., s. 110.

${ }^{13}$ Ibidem, s. 143-146. Wyrazem tego jest słynna już kwestia wypowiedziana przez wieloletniego ministra spraw zagranicznych i premiera Wielkiej Brytanii w XIX w. Henry'ego Temple'a: „Wielka Brytania nie ma wiecznych wrogów ani wiecznych sojuszników; wieczne są tylko interesy Wielkiej Brytanii i obowiązek ich ochrony". Maksymę tę często używaną także w publicystyce cytuję za: J. M. Kretek, H. A. Kretek, Analiza stosunków polsko-brytyjskich na przełomie XX i XXI wieku, „Eunomia” 2018, nr 1 (94), s. 148.

${ }^{14}$ Zob. J. Darczewska, Anatomia rosyjskiej wojny informacyjnej. Operacja krymska - studium przypadku, „Punkt Widzenia” (Warszawa) 2014, nr 42; eadem, Diabeł tkwi w szczegółach. Wojna informacyjna w świetle doktryny wojennej Rosji, „Punkt Widzenia” (Warszawa) 2015, nr 50; eadem, Wojna informacyjna Rosji z Zachodem. Nowe wyzwania?, „Przegląd Bezpieczeństwa Wewnętrznego” 2015 (wyd. specjalne), s. 59-73; M. Wojnowski, Koncepcja „wojny nowej generacji” w ujęciu strategów Sztabu Generalnego Sił Zbrojnych Federacji Rosyjskiej, „Przegląd Bezpieczeństwa Wewnętrznego" 2015, nr 13, s. 13-39; D. Kaźmierczak, Walka informacyjna 
Omawiając osiągnięcia Chodackiego z wykorzystaniem narzędzi charakterystycznych dla kilku dziedzin naukowych, Autor omawianego opracowania uznaje go za „prekursora badań nad bezpieczeństwem”. Podkreśla też, że „większość jego wniosków nadal jest aktualna i może być przydatna do analizy bieżących wydarzeń”. Dla oceny postawy Chodackiego istotne jest też to, iż bohater książki, podejmując się recenzowania polskiej polityki zagranicznej przed 1939 r., nie mógł być do końca obiektywny, jako jeden z bliskich współpracowników ministra Józefa Becka ${ }^{15}$.

Prezentując drogę życiową ppłk. Mariana Chodackiego i jego dorobek analityczny, Autor dobrze wypełnił zadanie, którego się podjął. Publikacja ma oryginalną konstrukcję, umożliwiającą klarowne przedstawienie przedmiotu badań. Biorąc pod uwagę argumentację Autora przytoczoną w rozdziale pierwszym, uznać ją trzeba za przemyślaną, zasadną i zwartą. Narrację cechuje poprawność literacka, która służy syntetycznemu opisowi wydarzeń, ocen i poglądów. Z jednym małym zastrzeżeniem, które powodowane jest stosowaniem pochodzącego $\mathrm{z}$ języka niemieckiego słowa „glajchszaltowanie". Ten germanizm - być może użyty celowo - charakterystyczny jest raczej dla języka potocznego ${ }^{16}$.

Bez wątpienia książka ma charakter nowatorski i wprowadza do obiegu naukowego nowe istotne ustalenia, którymi ze względu na jej interdyscyplinarny charakter mogą być zainteresowane różne kręgi odbiorców. Bezstronnie trzeba przyznać, że jest też ciekawa. Zaproponowane ujęcie tematu jest przemyślane i spójne, aczkolwiek w jednej warstwie pozostawia jednak u czytelnika pewien niedosyt. Autor, przygotowując ją, wykorzystał dostępne archiwalia oraz kolekcję Chodackiego, zdając sobie równocześnie sprawę $z$ tego, iż jako oficer wywiadu preferował on pozostawanie $w$ cieniu głównych wydarzeń. Trudno taką postawę uznać za element pomocny dla jego ewentualnych biografów. Prawdopodobnie też dlatego rys biograficzny Chodackiego jest pozbawiony raczej jego osobistych ocen, towarzyszących mu być może wątpliwości, odczuć, wreszcie emocji. Jego codzienność - także ta emigracyjna, już po zakończeniu służby - pozostaje nieodkryta. Z kart książki spogląda na czytelnika chłodny, zdystansowany, merytoryczny, wyzbyty ułudy „myślenia życzeniowego” i przez cały czas „kontrolujący się” oficer wywiadu i dyplomata. Można wręcz odnieść wrażenie, że jego życie osobiste czy rodzinne pozostawało zawsze w cieniu spraw i obowiązków

we współczesnych konfliktach i jej społeczne konsekwencje, „Annales Universitatis Paedagogicae Cracoviensis. Studia de Securitate et Educatione Civili” 2017, t. 7, s. 111-129.

${ }^{15}$ Zob. D. Smyrgała, Dwa kroki przed przyszłościa..., s. 203.

${ }^{16}$ Ibidem, s. 59. Termin oznacza: likwidować na siłę różnice w sposobie myślenia i działania ludzi. 
służbowych. Kwestią otwartą pozostaje pytanie, w jakim stopniu taki obraz ppłk. Chodackiego jest wynikiem świadomego zabiegu Autora czy może raczej rezultatem wzmiankowanego braku stosownych źródeł bądź informacji. Trochę szkoda, bo ten rys wzbogaciłby osobowość i znacznie uwiarygodnił go jako człowieka. Poza tym informacje z tego zakresu posłużyć mogłyby innym badaczom historii wojskowości czy dyplomacji. Być może wystarczającym wyjaśnieniem tych ograniczeń jest podtytuł książki, który zdeterminował perspektywę, z jakiej opisana została działalność Mariana Chodackiego.

Podczas lektury książki odczuwalne jest też zbyt oszczędne stosowanie odsyłaczy o charakterze zarówno biograficznym, jak i merytorycznym. Dodatnią stroną monografii pozostaje zaś jej warstwa analityczna sygnalizowana w podtytule pracy. W tym aspekcie wysoko należy ocenić umiejętności warsztatowe Autora, które stanowić powinny istotny punkt odniesienia dla innych badaczy. Podkreślić też należy, że główny cel pracy został przez Autora osiągnięty.

Mankamentem publikacji, na który należy zwrócić uwagę Autorowi i Wydawcy, jest brak indeksów (osobowego i geograficznego), wykazu skrótów i zrezygnowanie $\mathrm{z}$ umieszczenia $\mathrm{w}$ niej ilustracji. Braki te utrudniają korzystanie z książki i wpływają na jej atrakcyjność. Postulowałbym, aby w kolejnych wydaniach zostały one uzupełnione.

Na opracowanie Dominika Smyrgały należy popatrzeć jednak z szerszej perspektywy, którą wyznacza poświęcenie i profesjonalizm bohatera książki. Chodackiego cechowała bowiem uczciwość intelektualna, umiejętność oceny danej sytuacji, jak również gotowość do zmierzenia się z wyzwaniami i problemami współczesności. Prezentując postać ppłk. Chodackiego i jego osiągnięcia, omawiana książka wpisuje się w kanon lektur istotnych dla zrozumienia pokolenia, które wywalczyło niepodległość Polski w 1918 r., budowało jej podwaliny w dwudziestoleciu międzywojennym, a w wyniku rozstrzygnięć militarnych i dyplomatycznych II wojny światowej było świadkiem jej kresu i powstania Polskiej Rzeczypospolitej Ludowej. Choć trudno uznać Chodackiego za osobę pierwszoplanową tego środowiska, to z pewnością był dla niego postacią reprezentatywną.

Wyrażając zadowolenie z ukazania się recenzowanej publikacji, żałować tylko należy, że przez dziesięciolecia dziedzictwo ppłk. Chodackiego pozostawało zapomniane i nie mogło - w pozytywnym tego słowa znaczeniu - inspirować poczynań i wyborów kolejnych pokoleń Polaków. Należy też ubolewać, iż niejednokrotnie wnioski wysuwane przez „Maracza” w okresie wojny miały niewielki wpływ na ówczesnych politycznych decydentów ${ }^{17}$. Wręcz przeciwnie - jak udowadnia Dominik Smyrgała - były ignorowane

${ }^{17}$ Ibidem, s. 11, 136-143. 
i spotykały się z brakiem zrozumienia, ściągając na ich autora co najmniej kłopoty ${ }^{18}$. Kolejną kwestią, na którą warto zwrócić uwagę w kontekście recenzowanej publikacji, pozostaje fakt, iż inny wieloletni oficer polskiego wywiadu, kpt. Jerzy Niezbrzycki, który po zakończeniu wojny pozostał na emigracji, gdzie publikował pod pseudonimem Ryszard Wraga, do dziś uznawany jest zarówno za pisarza, jak i sowietologa ${ }^{19}$. Książka Dominika Smyrgały powinna, moim zdaniem, sprawić, że za podobny autorytet w tym zakresie uznawany będzie ppłk Marian Chodacki. Dobrą zaś okazją do utrwalenia takiej oceny może być zapowiadane wydanie jego pism. Publikacje te przyczynić się powinny do upamiętniania Chodackiego również w innej formie, czy to w rodzinnym Nowym Sączu, czy to w Gdańsku, gdzie ów oficer i dyplomata Rzeczypospolitej z poświęceniem bronił polskich interesów.

\section{Mariusz Krzysztofiński \\ (Oddziałowe Biuro Badań Historycznych IPN w Rzeszowie) orcid.org/0000-0003-3905-1684}

\footnotetext{
${ }^{18}$ Ibidem, s. 88-91.

${ }^{19}$ Nie przeszkadzało mu to pełnić we wspomnianym okresie roli konsultanta francuskich i brytyjskich służb specjalnych, jak również CIA podczas pobytu w Stanach Zjednoczonych. W opinii autorów zajmujących się historią polskiego wywiadu w II RP istnieją mocne przesłanki wskazujące na dwuznaczne relacje łączące kpt. Niezbrzyckiego z sowieckimi służbami specjalnymi. Zob. M. Świerczek, Ryszard Wraga, „O rewolucji”, „Przegląd Bezpieczeństwa Wewnętrznego" 2019, nr 20 (11), s. 198; Tajna wojna II RP. Wywiad z Marianem Zacharskim, [rozmawiał P. Zychowicz], „Historia. Do Rzeczy” 2014, nr 2 (12), s. 34.
} 